TIMOTHY T. SCHWARTZ

\author{
SUBSISTENCE SONGS: \\ HAITIAN TÉAT PERFORMANCES, GENDERED CAPITAL, \\ AND LIVELIHOOD STRATEGIES IN JEAN MAKOUT, HAITI
}

\title{
INTRODUCTION
}

Rural Haitian women assiduously negotiate sexual acquiescence to men and they do so with the goal of material gain. Ira Lowenthal (1984:22) first described this behavior in detail when he reported that women in his research community referred to their genitals as entere-m (my assets), lajan-m (my money), or manmanlajan-m (my capital), in addition to tè-m (my land); a common proverb was, chak famn fet ak yon kawo te - nan mitan janm ni (every women is born with a parcel of land - between her legs). Lowenthal (1984:22) described this type of female commoditization of sexuality as a "field of competition" wherein women are at a socially constructed advantage: Men are conceived of and taught to think they need sexual interaction with women while woman portray themselves and are taught to think of themselves as able to get along without sex and thus are able to exact material rewards for sexual contact with men. Called "gendered capital" by Karen E. Richman (2003:123), these sexual-material values are universal in rural Haiti and apply whether the woman in question is dealing with a husband, lover, or a more casual relationship. Moreover, the process is linked to a sexual division of labor and rights and duties associated with control of the household, extra-household income, and female marketing activities.

In this article I look at how gendered capital - or what may alternatively be described as Haiti's sexual-moral economy - is expressed in songs that rural adolescent girls compose, sing, and act out in theatrical performances called téat. Reminiscent of Jorge Duany (1984:186) who stated that the traditional song "cannot fail to create and recreate the most important social values of the group that produced it" and John Szwed (1970:220) who wrote that "song forms and performances are themselves models of social behavior

New West Indian Guide / Nieuwe West-Indische Gids vol. 81 no. 1 \& 2 (2007):5-35 
that reflect strategies of adaptation to human and natural environments," the songs I present highlight the uniform sexual-material-domestic value system found throughout rural Haiti. I use the songs as a mechanism to present and describe this value system in a remote rural area of Haiti called Jean Makout, a pseudonym. I try to show how sexual values in the area relate to matrifocality and subsistence strategies and in doing so attempt to explain how they came about and are maintained. Women, I explain, control production and reproduction in Jean Makout: They bear and rear children and in the process they exploit child labor to accomplish household chores, rear animals, and plant gardens, endeavors that ultimately free the women to engage in regional commercial marketing activities. The process is orchestrated largely by older mothers, full-time market women who extend their control over reproduction to that of their young daughters, allowing them (women) to ultimately determine the terms of sexual negotiation with men and putting older women on economically equal footing with men, indeed, often allowing women to economically dominate their spouses.

\section{THE SITE}

Jean Makout, Haiti, is a commune, or what in the United States is known as a county. It is made up of 168 square miles of one of the most geographically rugged, remote, and underdeveloped areas of Haiti. The 130,320 men, women, and children living there are mostly scattered throughout the countryside in 22,827 relatively dispersed homesteads and clusters of homesteads. The primary household livelihood strategies are small-scale agriculture, animal husbandry, and to a much lesser degree, fishing. There are no tractors, no electric labor-saving devices - no electricity at all - no piped water, no water pumps, and no mechanized fishing technology, not even, at the time of this research, outboard motors.

This is not to say that Jean Makout has been untouched by the world economy and global trends. In addition to 100 years of colonialism and slavery (1697-1791), the Jean Makout social system and the ancestors of most people who live in the region underwent thirteen years of bloody and violent social upheaval (1791-1804), 202 years of rule by a repressive Haitian state apparatus (1804-present), 141 of which were tempered by spiritual guidance from the Catholic Church, as well as nineteen years of neocolonial U.S. military occupation (1915-1934) and, most recently, fifty years of massive out-migration and an onslaught of internationally funded technical and nutritional aid programs arguably as intense as any place on the planet. These most recent trends, migration and foreign aid, have created a social system characterized by the flight of the elite and rural intelligentsia resulting in a system of ongoing abandonment that leaves the poorest and least educated behind and has given 
way to extreme poverty, a withdrawal into the local economy, and dependence on traditional subsistence strategies that involve virtually no mechanization and require high expenditures of manual labor (Schwartz 2001).

Lack of infrastructure and wage labor opportunities mean that the primary organizational unit of production is the household. Kinship ties and extra household work groups link individuals at the supra-household levels but it is through the household that the individual survives, and it is the labor demands met through household organizational strategies that are most conspicuous feature of the economy. Very importantly for this article, high labor requirements for households mean that people in Jean Makout are heavily dependent on their children for assistance. The importance of children and dependency on family labor is the key to understanding gender relations in Jean Makout.

\section{RESEARCH}

The data are based on five years living in the region, development reports, a 1,586 one-in-fourteen systematic random sample of all households in the commune (1,586 households). Additional surveys were conducted between 1998 and 2000 and included a gender and ecologically stratified, random, 136-household subsample of farmers' opinions regarding children and the purposes for having children, and three other surveys focusing on livestock and gardens, household labor demands, and marriage patterns. The surveys attempted to discriminate differences by regional and ecological zone but it was found that gender relations and livelihood strategies are remarkably uniform throughout the commune, as are the presented songs (see Appendix).

\section{GIRLS'TÉAT SONGS}

\section{Girls'Theater}

When school is out for the summer, girls in rural Jean Makout neighborhoods form dance troupes called téat (theater). The troupes are formed by the girls themselves. There is no adult sponsorship or leadership. The girls are all prenuptial, have not yet borne children, and are generally aged 10 to 20 years. Older girls appoint themselves troupe directors and instruct the younger girls in daily practices. The girls dress in short skirts and sing while performing the latest erotic dances such as the buterfli (butterfly), a dance in which the girls gyrate, opening their legs wide and rocking their abdomens out toward the impromptu audience as they descend lower and lower toward the ground. The songs are improvised from bits of other songs and spiced with the girls' own creative additions. The most popular songs are imbued with sexual con- 
notations such as the following, in which the girls celebrate their own budding sexuality with respect to the sexual bravado of men,

\author{
Look here, it is mango season \\ Look here, the mangos are sweet and beautiful \\ Good day young lady, I say to you good day \\ It is a plantain that has come to make things sweet \\ It's Pepsi Cola I drink. It is Coca Cola I drink \\ It's Pepsi Cola I drink. It is Coca Cola I drink \\ Vwasi lè mango, \\ Vwasi lè mango, yo dous e yo koket \\ Bon swa madamwazel mwen di ou bon swa \\ Se yon banan ki vini pou-l sikre
}

Se pepsi kola $m$ bwe, se koka kola $m$ bwe

Se pepsi kola $m$ bwe, se koka kola m bwe

The song relies heavily on metaphors, and in this particular one, informants explained that mangos, ubiquitous in Haiti and the all-time favorite fruit, symbolize the girls' budding young breasts. The eroticism of fruit and particularly a mango with its soft juicy flesh is clear to native speakers; the declaration that "it is mango season," means that it is time to eat mangos, the fruit is ripe, or rather, the girl has come of age and she is ready to engage in sexual relations. The "good day young lady" is an introduction to the young woman and the next line reveals the speaker, a man, represented as another fruit, a plantain, which is not sweet but has nevertheless come to add sugar (sikre), and happens to be the most phallic-shaped fruit in Haiti, leaving little doubt for analysis (any remaining doubts are erased by snickering Haitian informants). The references to Pepsi and Coca Cola are metaphors for prestige. In Jean Makout these are, aside from beer, the most expensive locally available beverages and they have correspondingly high prestige value, representing the speaker as a high roller.

Thus, the songs reviewed here all touch on the theme of sex. The songs also highlight female ideals and aspirations, gender relations, control over resources, parental-daughter relationships, and most importantly of all, the rules, expectations, and norms associated with male-female sexual interaction, all of which, I argue, are interrelated in what might be called a type of sexual-moral economy. The analysis, conducted with the assistance of local informants who helped explain the double and sometimes triple meaning of the words to the songs, begins with a look at a socially constructed problem that Jean Makout women have and the representation of that problem in téat songs. 


\section{Male SeXual AgGressiveness}

A common expression used by women in Jean Makout is "men are dogs" (gason se chyen); "men can not get by without having sex" (gason pa ka rete san fi). No strong prohibitions exist in Jean Makout against men seducing young women and Haitian laws that prohibit sex with girls under fifteen are not enforced. Men in their fifties, sixties, and even men in their seventies are referred to with regard to their sexuality as jenn gason (young men) and powerful men may have four or five and even six common-law wives, a source of pride and esteem. Thus, young women are badgered and cajoled by a relatively large pool of socially eligible, sexually active, and highly aggressive men. The most common seduction tactic is for a man to catch a woman on a footpath or while she is alone in the kitchen. He will seize her arm so she cannot get away, playfully trying to pull her near, proclaiming his desire for her and pleading for her sexual affection while whispering promises of money and gifts.

As counterintuitive as it might at first seem, females arguably play an influential role in encouraging aggressive male sexual conduct. They take part in propagating the myth that a celibate man can go insane, become ill, and may die. They tease timid boys and ridicule celibate men, taunting them with names like jay-jay (retarded) and masisi (homosexual); and they goad younger brothers and even sons into pursuing nubile young women with comments that sound to the Westerner like admonitions to rape, "you must bother them, don't let them get away, grab them" (fo ou jennen yo, pa kite yo ale, fo ou kenbe yo). The influence of women in conditioning male attitudes begins at an early age, as exemplified by the fondling of the genitals of male infants, toddlers, and boys up to the ages of 9 and 10 years, something so thoroughly engrained and accepted as to appear to the foreigner to be below the level of awareness. The fondling is made easy by the custom of making prepubescent boys go without pants. Examples of the context in which it occurs include the following: A rural woman nervous about being interviewed by the author distracts herself by fondling a 4-year-old's penis all the while she is answering questions; a 19-year-old woman sitting on a bed in a dimly lit hut talking to the author reaches beside her and, without ever looking at what she is doing, begins fondling the penis of a naked 8-year-old boy, and does so as nonchalantly as if she had just picked up a pen or any other stray object off the table; a 22-year-old woman excited to see her 2-year-old nephew tickles his penis, lifts the boy, swings his body up to her face and pops his penis playfully into her mouth. The toddlers and young boys are not indifferent to the treatment and react with enthusiasm, smile and laugh when given the attention, and often follow their significant female others around. The song below playfully alludes to, or is at least suggestive of the active role that Jean Makout females play in determining male sexual identity and the coy preservation, or at least guarded access, to their own sexuality, 


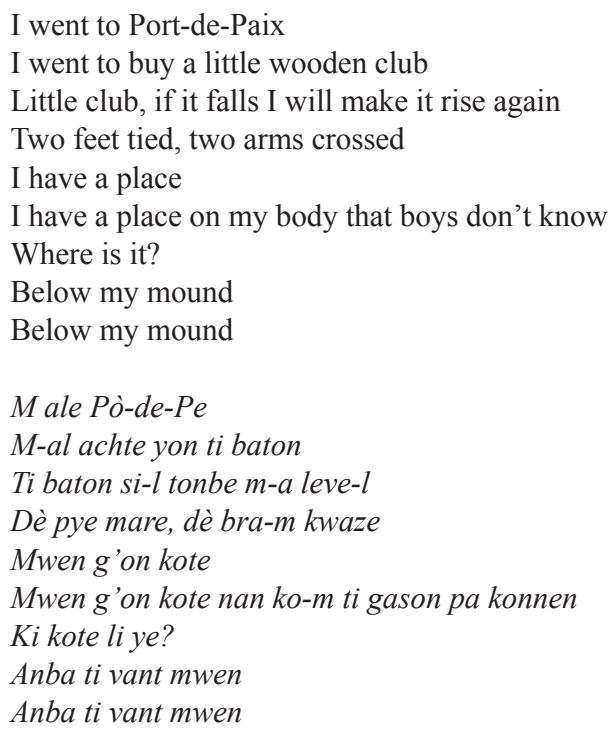

The reference to "a little wooden club" is an obvious phallic allusion (clubs are not something that everyone in Jean Makout is walking around with, and while old infirm people might use a cane, purchasing one is nonsensical). The line, "if the club falls," signifies the loss of an erection and this image is reinforced by the next line which in Kreyol uses the verb leve (rise) and anko (again) - "I will make it rise again" - rather than ranmase, the Kreyol word for "pick up" - "I will pick up the club." The next line, "Two feet tied, two arms crossed," suggests restraint or prohibited access to the woman's sexuality. The remaining lines, "I have a place boys don't know ... under my mound" are a proclamation of virginity and chastity: "under my mound" is translated from "anba ti vant mwen," it literally means "under my little stomach." In effect, the girl may choose, "buy," a penis to fondle, making it rise again and again, but her own genitals have never been "known" by boys.

\section{Chastity And The Commercialization of Female SeXuality}

Although women encourage men to be sexually aggressive and inculcate in boys the association between females and sexual stimulation, they are not themselves so willing to comply with the amorous wishes of men. The socially constructed attitudes of Jean Makout women are contrary to that of men. While admitting that they desire sex, women define themselves as not needing it. Despite the "hot" tone of the songs, they always include restraint, as in the previous song, "two feet tied, two arms crossed ... I have a place 
that boys don't know." All Jean Makoutiens know and commonly say, "girls do not flirt with boys" (fi pa konn koze a gason). It is the boy's job to flirt. Sexually aggressive women or those who engage in sex for pleasure are criticized, as in "she is such slut" (tann li bouzen), or insultingly called "nymphomaniac" (piten). A young woman who has not had children and is not in union will always insist she is a virgin, no matter what her personal sexual history might be; and as a matter of identity and pride most Jean Makout women insist, often and quite publicly when the subject arises, that they can live without sex. They describe themselves as sipotan (able to tolerate abstinence). They maintain an attitude of sexual indifference, describing excessive sexual intercourse as painful, a burdensome service they provide to men, and while admitting that sex can be fun, and even exalting its pleasures, they consider over-manifestations of their own biological interest in sex to be a fault, something evident in attitudes toward vaginal secretions during sex. Commonly thought in Western society as a biological sign of sexual arousal, Jean Makout women who become more than slightly wet are called bonbon dlo (watery vagina), considered disgusting; and women make efforts to dry themselves if the condition manifests itself during sex, even if the sex is with their husbands.

As in studies mentioned from elsewhere in rural Haiti (Lowenthal 1987, Richman 2003), the defining feature of female attitudes toward sexual relations in Jean Makout is that they view their sexuality as an economic asset. They say that they are born with a carreau of irrigated land between their legs (the most valuable asset in rural Haiti); and they refer to their genitalia in exchange terms, byen-pa-m (assets/goods), excusing each other for engaging in an affair outside of conjugal union so long as the man reciprocates with material rewards: "She is a woman isn't she? It's her right"; "Getting by is not a sin" (degaje se pa pech). Men are acutely aware of the rules, and they commonly say, "in order to have a woman you must have money" (pou gen fi, fo gen lajan), and "women eat/devour men," meaning they take all a man's wealth ( $f i$ konn manje gason). A woman's right to exchange sex for financial reward is exalted in the following song which according to informants is actually a metaphor for sex and a demand for payment,

I need a couple of dollars

Why do I need couple of dollars?

To buy a ribbon, to tie around my waist, to make my hips shake/the dance work

Just throw it in my alley, two dollars

Just throw it in my alley, two dollars

Just throw it in my alley, two dollars 


\author{
Mwen bezwen dè dola \\ Sa pou-m fe dè dola? \\ Pou achte yon ribon pou fe lamayet mache \\ Lage li nan riyèl la, dè dola \\ Lage li nan riyèl la, dè dola, \\ Lage li nan riyèl la, dè dola
}

This song humorously summarizes the attitudes with which Jean Makout women imbue their sexuality. As with the other songs, it is a play on words, but words already very sexual. The Kreyol term lamayet designates a sexy dance movement and informants explained that it is combined with the word mache (to function, operate, work) to form the implied verb "to hump" make the dance (lamayet) function or less suggestively, to enable the girl to better shake her hips. Lage literally means "to let go" and a Haitian male "come on" is, lage-m nan reyal la, which means, "let me loose in your alley." But in terms of money a very common colloquialism is, lage sink goud nan min mwen, (let a dollar go in my hand). Thus, lage li nan reyal la is a play on these two expressions and to state it literally, it means, "just throw the money in my vaginal canal." So the song is a rather ingenious circular play on words that reduced means, "I need two dollars. Why? Because if you want me to perform sex that is what it costs to get my hips going. So just throw the two dollars right in my vagina." The Jean Makoutiens who reviewed these songs with me could hear this particular song several times in succession and laugh hysterically every time.

\title{
The Sexual Market and Negotiating Gender
}

Male sexual aggressiveness and female chastity coupled with the material demands women attach to sexual acquiescence set the grounds for a negotiated struggle between the genders: Men want women to grant them sexual favors; women want material goods and money. Young, old, and those men already in common-law union or married harass and plead for sexual favors from young women who are not yet in union. But wanting sex is one thing; getting it is another.

No matter how much a woman might be attracted to a man, she is supposed to resist, and at the heart of the issue of resistance is the value of her sexuality and what the man has to offer in exchange. A woman will indicate her receptiveness by providing the man with cooked food when he visits her at her mother's home. But she must not concede, she must not respond to sexual advances. She holds out for gifts and money. Unless in utter secrecy, no self-respecting young Jean Makout woman will give any open indication of sexual acquiescence before the gift of gold earrings and a gold chain, the 
defining symbol of a man's intentions to play by the rules. And if the man hopes for continued receptivity he must continually bring gifts, meat, garden produce, and store-bought presents from town, a handkerchief, perfume, a porcelain figurine. To the extent that he does this the woman will manifest her willingness, reciprocating with domestic service, washing clothes, providing water for him to wash and, as the man demonstrates his generosity, acquiescing to sexual contact. All of this ideally occurs under the watchful eye of the young woman's mother.

Some men, of course, try to cheat. They try to get something for nothing by not living up to their pretenses, by not fulfilling the financial responsibilities that men have to lovers and to the mothers of their children. Women and their families strenuously object to this behavior. Throughout Haiti the most widely used insult for men and one that has a very exact meaning is vakabon, a name with legal-historical origins - the crime of being a man with no money or job, but that today specifically denotes a playboy who does not meet his financial responsibilities to lovers, wives, and offspring. The vakabon is a major concern to Jean Makout women and a recurrent theme in téat songs:

\footnotetext{
Young men, they are not working, they do not have just one girlfriend Young women think they have money

The men offer engagement and the girls give their whole body to them Then the men ignore them, turn their backs and go If you see I am carrying a gift it is for my godmother Accompanied by another for my godfather Godfather come and get it, you must come and get it in the butterfli If you can not come get it in the butterfli, you can not have it
}

\author{
Jen gason yo pap travay, yo pa kondi yon sel menaj \\ Jen fi yo pa panse si yo pa gen lajan \\ Lè yo we yo finanse, yo lage tout ko bay yo \\ Lè sa yo meprize, yo vire do yo ale \\ Si ou we m pote yon kado se pou fe marenn kado \\ Akompani a yon lòt, se pou parenn mwen li ye \\ Parenn mwen $w$-ap vin pran, $w$-ap vin pran nan butterfli \\ Si ou pa pran nan butterfli, ou pa ka vin pran nan min
}

In this song the girls complain, and warn, that many young men dress smartly and act as if they have money when in fact they do not. They bluff young women, promising money and marriage for sex. Girls who fall for it are subsequently abandoned. There is then a refrain about godmothers. Godmothers are like mothers, special, female, and deserving of gifts. In the next line the girl, says the godfather, "must come and get it in the butterfli," a sexual allusion. The only butterfli in the Kreyol language is a dance movement mentioned earlier where girls spread their legs, thrust out their abdomen, and 
gyrate. Thus the metaphor means, "to take it from the girl's crotch," echoing the exchange relations between the genders because, as Jean Makoutiens know, the only gift a Jean Makout woman should give to a man is sex, not material goods - it is men who give material goods to women. The same rules in a modified form extend into conjugal union; and it is at this stage that the link between subsistence and sexual-moral economy begins to become clear.

\section{CONJUGAL Union And THE PROVISION OF A House}

The building of a house is the single most important event that occurs in the legitimization of a union. A couple may have several children but until the man has provided her with her own house, they are not considered in union nor is the woman bound by obligations of fidelity. Even legal marriage is dismissed and legally vacuous if the man has not provided a house for his wife.

The value of a woman's sexuality is so closely linked to material exchange and house building that in cases of rape, marriage between victim and assailant is a possible penalty, particularly if the parties are young and particularly if the man is of higher socioeconomic status. In a case that occurred in a community where I was living, a 25-year-old man was convicted of raping a 14-year-old girl. His punishment: To buy the girl a gold chain, earrings, and to promise marriage. The parents took the chain and earrings but citing the man's poverty, "that good-for-nothing can not provide anything for our child" (sansave sa pa ka regle anyen pou pitit pa nou), they insultingly sent the man a female dog in their daughter's stead. If the man is already married, a financial indemnity is the usual outcome. If the woman is married or in a consensual union with another man, the situation is different - and rare. The rapist is considered to have threatened the continuation of the marriage, as the husband may leave his wife. Severity is the rule and the assailant will be going to prison, if the girl's family does not manage to kill him first, and his family will have to pay the woman and her husband a sum that according to local judges may include the loss of all or most of the man's property.

The relationship to sexual access, exchange, and the provision of a house is metaphorically represented in the following téat song,

\footnotetext{
A place, I need a place

To spin myself around

Underneath my house (dress)

I have an adult

Who is shaking me
} 
Kote, $m$ bezwenn yon kote

Pou-m liete ko-m

Anba lakay-um

Mwen gen yon gran moun

Kap sakaje-m

In this song the girl is saying that she needs to break out of the confinement of being a child and of social constrictions, "a place I need a place, to spin myself around." She then gets right to the point, "under her house," which informants explained as also meaning "under her dress," she has "an adult who is shaking her." The thinly disguised sexual meaning is that the girl's genitals are mature, "adult," and they are frustrating her, she is yearning to use them, yearning for sex, she can not stand it any longer, she must find a place to let herself go, she must find a man, she is ready. The song seems to challenge the female rule not to be overtly sexual but it must be remembered that women do not deny their sexual desire; they emphasize that unlike men, they can control it and in this way is meant to be sexually teasing as in, "I have what you want, it is ready, but you must first provide me with what I need, a place and a house." To further clarify the point, there are dual and even tri-metaphoric references in the song, references that hit on key themes in Jean Makout gender relations and the demands and aspirations of women. Specifically, women in Jean Makout are thought of as the owners of houses, and a girl does not become a fully recognized adult until she has established her own homestead. But it is that man who, if he wishes to win exclusive sexual access to the woman, must build her a house. Thus, by allusion the girl is saying that she is adult, she has the skills to manage her own home. All she needs is a man and the house he will provide; and by metaphor she is a house and is stating that "she needs a place" for herself, her house. She is ready to be a woman, she has an adult inside shaking her.

\section{DOING YOUR PART}

Once a house has been built, the inviolable rights and duties associated with the union begin and they carry the weight of both custom and law. For his part, the man must plant gardens and raise livestock for the household. He may come and go as he pleases. He may even take other wives and plase them (build a house for them and provide gardens and livestock). But under no circumstances may he lead another wife or lover into the yard or share products of that particular homestead with another woman. So long as he is fulfilling these obligations, the woman, on her part, must be faithful, another value expressed in a téat song that plays on the word plase, using it here as 
literally meaning, "to get stuck," but with its metaphoric suggestion, to enter union, and suggesting fidelity,

I'm like corn chaff, I'm like corn chaff

Everyone knows I am like corn chaff

Wherever I plase, I don't deplase

Everyone knows I am like corn chaff

When Cedras was president

Children did not make love young

Now Brother Preval is president and children make love at a year old

Se pay mayi, se pay mayi

Tout moun konnen m se pay mayi

Kote $m$ plase, $m$ pa deplase

Tout moun konnen me se pay mayi

Lè Cedras te la,

ti moun pat reme bonè

Kounie-a se fre Preval, Ti Moun reme sou en an

The reference to corn chaff and its clinging effects is a humorous allusion to bits of corn that tend to get stuck in the teeth. The phrase "wherever I am plase I don't deplase" is a play on the word plase which can mean two things, consensual union or to be placed, and deplase which means "to move or be moved." The girl is saying that she is like corn that gets stuck in your teeth, she will not let go easily, also meaning that once she is given a house and enters union with a man she will stay put, she will not abandon him for another man, she is loyal. The rest of the song is a lauding of entrance into sexual activity at an early age: When Cedras the mean military dictator was in power children could not "reme" (go steady) at an earlier age. Now that the nice "brother Preval" is running the country, children can engage in relationships at the ridiculously early age of one year, an echo of the lack of proscriptions against seducing young women, but conspicuously attached to provision of a house, plase.

\section{CONTROL}

It is the woman who is in control of the household, expenses, and household production. Women take care of the house, clean, wash clothes, make meals, carry water, and purchase basic foods and necessities at the market. Women also sell garden produce in markets and they often specialize in selling a particular staple or item out of the house such as rice, sugar, candles, or soap. A woman who has a husband who is present will typically not participate 
in preparing fields or weeding, but women are considered indispensable in planting, and more importantly, for the daily picking of produce and seasonal harvests. Harvesting is considered to be the exclusive domain of women and is typically coordinated by the ranking woman of the house.

Table 1. Who Needs the Other More, Husband or Wife?

\begin{tabular}{lccc}
\hline & \multicolumn{3}{c}{ Respondents } \\
\cline { 2 - 4 } & $\begin{array}{c}\text { Men } \\
(\mathrm{n}=69)\end{array}$ & $\begin{array}{c}\text { Women } \\
(\mathrm{n}=69)\end{array}$ & $\begin{array}{c}\text { Men \& Women } \\
(\mathrm{n}=138)\end{array}$ \\
Husband needs wife more & $28 \%$ & $23 \%$ & $26 \%$ \\
Wife needs husband more & $3 \%$ & $13 \%$ & $8 \%$ \\
They both need the other equally & $70 \%$ & $63 \%$ & $68 \%$ \\
Total Responses & $100 \%$ & $100 \%$ & $100 \%$ \\
\hline
\end{tabular}

Thus, men and women depend on one another in a socially constructed symbiosis, a need manifest in responses to the question, "can you get by without a spouse?" 86 percent of respondents said no. But reflective of the sexual values described above and of the superior bargaining position of women by virtue of their monopoly over the means of reproduction, men are conceived of as needing women more than the other way around: only 13 percent of women reported that a wife needs her husband more, but 23 percent of women reported that a husband is in greater need of his wife. Similarly, only 4 percent of men interviewed said, yes, they would live without their spouse; in comparison, 24 percent of Jean Makout women said they could live without a husband.

Table 2. Response to, "Can you get by without a spouse?"

\begin{tabular}{lccc}
\hline & $\begin{array}{c}\text { Men } \\
(68)\end{array}$ & $\begin{array}{c}\text { Women } \\
(68)\end{array}$ & $\begin{array}{c}\text { Total } \\
136\end{array}$ \\
\hline No & $96 \%$ & $76 \%$ & $86 \%$ \\
Yes & $4 \%$ & $24 \%$ & $14 \%$ \\
\hline & $100 \%$ & $100 \%$ & $100 \%$ \\
\hline
\end{tabular}

$($ Chi-sq $=10$, bilateral $\mathrm{p}(\mathrm{y})=.001)$ 
Bearing in mind the greater value of the woman in managing and maintaining the household, a man's provision of a house, gardens, and animals can be understood as a type of contractual partnership in which in exchange for these material goods a woman cedes over access to her ability to reproduce, the resulting children, and her and her children's labor. But she is still in control. People in Jean Makout say, gason dwe fe kay, min gason pa gen kay (men have a duty to build houses but they do not have houses). Should a man fail to provide for his spouse and children, the woman has the right to cuckold him without being expelled from the house. The point cannot be understated. For a woman who has borne children with a man, all the property inside the house, all that is in the yard, and all the gardens that a man plants and that are not tagged for another woman belong to her (specifically, they belong to her in the name of the children she has borne with the man). Custom and law reinforce the preeminence of the woman's right to the household and the associated production. Should a man and woman argue, it is the man who must leave, and he takes only his clothes with him - "and his radio," as informants jokingly added, "if he has one."

For outsiders who think that Haitian men can violate these rules by physical intimidation and violence, the reality is usually different. Women in Jean Makout can be and often are more ferocious than men. They also have their brothers, fathers, and sisters, all of whom will, if it is clear that the woman's rights are being abused by a man, join her in violent confrontation. In seventeen violent incidences I recorded while living in one Jean Makout community, only four involved men only; eight began with a conflict between a man versus a woman, in only three of these cases the woman was slightly injured, and in four cases the man was severely beaten; in two he almost died. Women also have recourse to the legal system, and judges enforce the rules described. ${ }^{1}$

Thus, women in Jean Makout tend to be tough and they aggressively assert their control over household expenditures. Husbands who impinge on their wives' sovereignty in the financial sphere are resented. Teenage girls sing the following téat song with glee:

1. In Haitian urban areas domestic violence against women is widespread. I believe this is a consequence of the large difference in male versus female economic opportunities and the relative absence of family - parents, brothers, sisters, uncles, and cousins - who can protect or even seek revenge for the woman. I do not believe, nor does my personal experience suggest, that violence against women occurs in rural areas to anywhere near the same degree. (Indeed, as seen, women appear more violent than men.) I believe this lower occurrence of domestic violence against women is a consequence of the exact opposite conditions to those found in the city: first, rural women have higher economic status visà-vis men than their urban counterparts, and second, family members are present and they often retaliate against violence to their daughters, sisters, mothers, and cousins. 


\begin{abstract}
My little Saint Ann
I am going to make a demand

I don't know if it will be granted

But I must make that man quit being stingy

I don't know if it will be granted

Men from ... like to count the dumplings in the pot

Mon ti saint ann

Mwen pral fe yon demann

Mwen pa konnen si lap bon

Pou-m ka fe gason kite saf

Mwen pa konnen si lap bon

Mwen pral fe gason an kite konte boy nan chodie

Se premie se denie pou-m kite ak neg ...

Neg ... remen konte boy nan chodié
\end{abstract}

I am going to make that man quit counting dumplings in the pot

It is the first time, it is the last time that I will be with a man from ...

Saint Ann is a reference to a deified idol, a doll found near the north coast town of Anse-à-Fleur where there exists a waterfall and annual pilgrimage site of voudou and Catholic zealots. The doll was found several years ago by a mambo (female shaman), who keeps it in a shrine. During the annual pilgrimage people come to ask wishes and favors of the doll. Thus, the girl is saying that the man is such a nuisance with his stinginess that she is going to go to Saint Ann and ask to change his behavior. This is also a nice way of threatening sorcery, and in this she would be justified by local standards because the man is overstepping his bounds. The meaning of the man "counting dumplings" is that he wants to see just how much food his wife is preparing with the objective of calculating how much she is spending, on what, how much she is eating, and who is getting to eat it, all responsibilities in the domain of the woman. The reference to dumplings is also, as indicated by one informant, a sexual one. In the game called Krik Krak, a Haitian game of riddles, a local riddle is "a dumpling in a cup." The answer: sexual intercourse, or more bluntly, a penis in a vagina (dumplings, called boy, are long and phallic shaped), so that one metaphoric suggestion is that the man counting "dumplings in the pot" is counting how much sex he is getting from his wife. The girls who sing the song tease men from certain zones in Jean Makout with the common refrain, "It is the first, it is the last time I will be with a man from 'such and such place,' men from 'such and such place' like to count the dumplings in the stew pot." 


\section{Men And Their PRoblem: Money}

Some observers might interpret the marital expectations depicted above as favorable to men. In contrast to women who are confined to the drudgery of the homestead and bound by expectations of sexual fidelity, men have nearly unbounded sexual freedom. But women are not bound to the homestead: They have the regional rotating market system, a domain of entrepreneurial activity monopolized exclusively by women. Furthermore, men too want homes. To break free of the bounds of parental control and achieve a minimum of economic autonomy a man must build a house and start a home. But he must first find a woman to make the home productive. It is his spouse who will wash his clothes, make his meals, fetch water, and go to market. He will not be having a great deal of luck seducing other women in the meantime. Female chastity and the financial demands that women attach to their sexuality mean that until a man has demonstrated that he is a dependable source of income his success in sexual ventures depends on lies and deceit, behavior that, if successful at all, only begets failure, as it earns him the reputation of a vakabon and quickly destroys, or at least makes greatly difficult, success with other young women. In short, any way that a man approaches the issue, the financial demands that women attach to their sexuality creates a major problem for him: money.

Many young men cannot afford union. In search of money so they can court a woman, buy gold earrings and a chain for her, and begin to build a house, some migrate, causing the proportion of males to females in Jean Makout to drop by 7 to 10 percent for the 20 to 49 year age group. Rather than delay the onset of childbearing waiting for male age cohorts to come back from the city or to become financially mature at home, most young Jean Makout women enter into union and begin bearing children with men who are older and have the financial means to provide for them. Thus, 49 percent of Jean Makout men do not enter union until their thirties while 48 percent of women are already in union before the age of twenty-five. At least a large minority of the men with whom women consent to enter union already have a spouse. In a sample of 122 men over fifty years of age, 40 percent of them had been, at some time in their life, simultaneously engaged in union with more than one woman.

\section{The Key to THE JeAn MaKout SEXual-Moral ECONOMY: CHILDRENS' ECONOMIC CONTRIBUTIONS TO HOUSEHOLD PRODUCTIONS}

Although it takes a man's financial and labor contributions to establish a Jean Makout household and a woman's to manage it, children make the household a viable unit of production. The labor value of children in Jean Makout, even very young children, cannot be gainsaid, and any observer who denies 
the importance of children in the endeavor to survive and maintain living standards is neglecting the harsh environmental and economic reality of life in rural Haiti. A household cannot sustain itself without child labor. Only 5.4 percent of households ( 85 of the 1,523 reporting) in the main survey upon which this study is based had no children - compared to 12 percent of households with no adult woman present full time and 23 percent of households with no adult male present full time. Fifty-seven percent of these childless households ( 47 of 83 for which the data is available) were in yards with other houses that did have children, indicating that only 36 of 1,523 houses (2.4 percent of the total) were actually homesteads without children. ${ }^{2}$

In Jean Makout it is emphatically child labor that determines the productive capacity of a household. Children perform household chores, they cook, they clean, they retrieve water, they go to the market, they work in the garden, and they tend livestock. In a test of the importance of children, the number of 7- to 25-year-olds present, who were not either the household head or the spouse of the household head, was found to explain fully .33 of the variance in ownership of animals and .33 of the variance in the number of gardens planted. This relationship was originally expected to be a byproduct of the age of the household head - i.e. the older the household head, the more land, animals, and children he or she had accumulated. But when age of the household head was statistically controlled by adding it to the regression equation, the model still explained .32 of the variance in number of household gardens and .20 of the variance in number of household animals (statistics originally published in Schwartz 2004).

The skeptical reader may not be convinced that more children translates to greater wealth. It could just as easily be said that more children translates to the need for more gardens and more animals. Jean Makout farmers, however, needed no convincing. In an opinion survey of 68 women and 68 men randomly selected from my original 1,586 household baseline survey, farmers overwhelmingly emphasized that children are not just helpful, they are necessary; and they are necessary because they work.

Why does a person have children? To help. Right now for example, I would have to go get water. But I don't have to. It is here. I would have to go get wood. But I don't have to. It's right here.

(40-year-old mother of 5)

If I did not have them, things would be worse for me. You need a little water, they go to the water. You need a little firewood, they go get wood. The boys work in the garden for you. They look after the animals.

(33-year-old mother of 8)

2. $\mathrm{N}=1,523$, missing $=66$. 
Children are the biggest necessity. If you need something you tell a child. Like right now, I can say, "go look for some firewood," or "some embers from the neighbors" house." "Go to the market."

(27-year-old father of 3)

Children are so valuable that, as mentioned earlier with regard to adolescent girls and restaveks, household heads are eager to take in children from other families. Few are able to do so; only 2 percent of children in the baseline survey were living in homes other than those owned and managed by their mother, grandmother, or another close family member. ${ }^{3}$

Table 3. Child Residence Patterns: Relationship of Child Household Members to Head of Household

\begin{tabular}{lcc}
\hline & Frequency & Percent \\
\hline Child & 4,866 & 79.74 \\
Grandchild & 609 & 9.98 \\
Niece/Nephew & 180 & 2.95 \\
Sibling & 137 & 2.25 \\
Cousin & 69 & 1.13 \\
Restavek & 66 & 1.08 \\
Stepchild & 50 & 0.83 \\
Godchild & 18 & 0.29 \\
Sibling-In-Law & 18 & 0.29 \\
Friend & 16 & 0.26 \\
\hline Total & 6,029 & 100.00
\end{tabular}

Missing = 86; Children under 19 years of age

3. The value of children means there are no true orphans in the area, not in the sense of being without someone to care for them. In a study of virtually all orphanages in the entire northwest département of Haiti, in which Jean Makout is but a small part, I found that virtually all functioned in a manner similar to boarding schools in the United States: most children had parents, most were not from the ranks of the poorest of the peasants, but rather the Haitian orphanage managers shared access to free books, education, and overseas contacts with offspring of wealthier peasants, their own family, and even with offspring of adults who had migrated to Miami. In some cases the orphanage owners had sent for relatives in the city to be "orphans." In other cases peasants rented their children to the orphanage in exchange for part of the money sent by the child's overseas sponsor. 
Chart 1. Respondents Preferring Six over Three Children

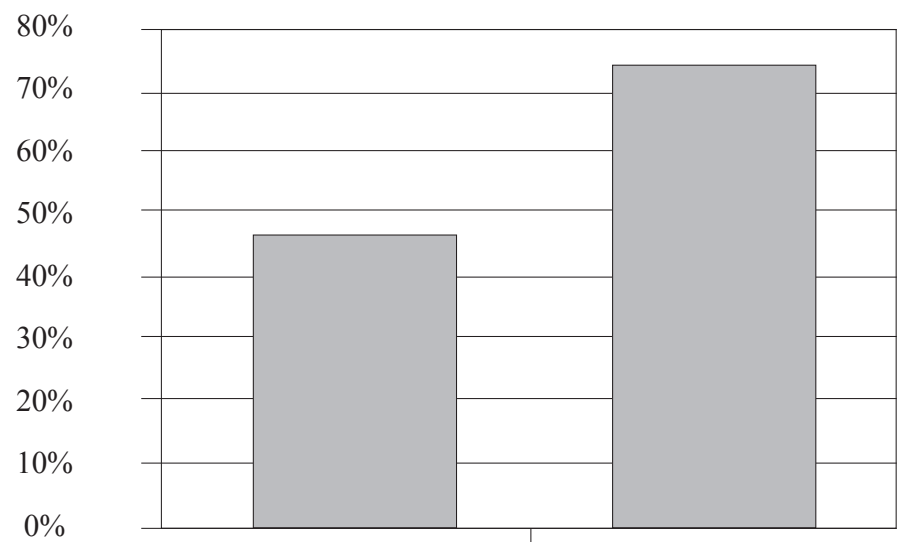

Children are especially valuable to older people and especially older women who control homesteads. When asked "which is best, for a man and woman to have three or six children?" 45 percent of men favor the larger family versus 72 percent of women who favored the larger family. Responses also varied substantially by age. Women over 50 were far more inclined than any other male or female age category to choose the couple with six children: Fully 87 percent (20 of the 23 women) chose the couple with six.

Table 4. Preferred Number of Children by Age and Sex of Respondent

\begin{tabular}{|c|c|c|c|c|c|c|}
\hline & \multicolumn{3}{|c|}{ Age Categories } & \multirow[b]{2}{*}{ Total } \\
\hline & & & $20-34$ & $35-49$ & $50+$ & \\
\hline \multirow{6}{*}{$\begin{array}{l}\text { A couple with three } \\
\text { children versus a } \\
\text { couple with six, who } \\
\text { is better off? }\end{array}$} & \multirow[t]{3}{*}{ Men } & Three & 10 & 11 & 14 & 35 \\
\hline & & Six & 3 & 13 & 13 & 29 \\
\hline & & Total & 13 & 24 & 27 & 64 \\
\hline & \multirow[t]{3}{*}{ Women } & Three & 10 & 6 & 3 & 19 \\
\hline & & Six & 13 & 16 & 20 & 49 \\
\hline & & Total & 23 & 22 & 23 & 68 \\
\hline
\end{tabular}

Missing $=4$

Older women's preference for more children than younger women has to do with the economic benefits that accrue to older women with many children at their disposal. With greater numbers of children women begin to plant their own gardens and to raise more animals, activities that free her from dependency on a husband. Among the 24 percent of women seen earlier who said that they could live without a man (see Table 2), it was in fact entirely women with three children or more who said so (Table 5). 
Table 5. Women Who Say They Can Live Without a Husband by Number of Children

\begin{tabular}{|c|c|c|}
\hline \multirow{2}{*}{$\begin{array}{c}\text { Women who say they can live } \\
\text { without a spouse }\end{array}$} & \multicolumn{2}{|c|}{ Number of Children } \\
\cline { 2 - 3 } & $\begin{array}{c}0-2 \\
(\mathrm{n}=10)\end{array}$ & $\begin{array}{c}3-5 \\
(\mathrm{n}=58)\end{array}$ \\
\hline Yes & $00.0 \%$ & $27.0 \%$ \\
No & $100.0 \%$ & $73.0 \%$ \\
\hline
\end{tabular}

Women made no secret about the value of children in helping them attain economic independence from husbands, commonly responding with statements such as,

What makes me say I can live without a man? What I need to do to come up with a sack of food I can accomplish with my four children.

(30-year-old mother of 4)

If I have children, I don't need my husband at all. Children, hey! hey! I would like to have ten children. I don't need my husband.

(41-year-old mother of 7)

Why can I live without a man? I arrive at an age like this. All my affairs are in order. I don't need my husband anymore.

(56-year-old mother of 8)

Equally or more important than livestock and gardens, child labor frees a woman to enter fully into a career in marketing, an endeavor that is, after gardens and livestock, the third most important source of income in the region, one that can put women on economic footing equal to and sometimes substantially greater than men. And as indicated by the women who say they can live without a husband, success comes with age and with children. A Jean Makout woman with four to eight children is four times more likely to be engaged in commercial activity than a woman with zero to three children.

Freed by the help of children, the most successful women sometimes build their trade revenue up to several thousand Haitian dollars per month. They buy agricultural land and animals, invest in a wide assortment of business ventures and sometimes even hire men to work gardens for them. Houses that have a woman in her 40s, 50s, and 60s are almost invariably known not by the husband's name, but by the name of the woman, as in Ma Zel's house or Lili's place.

But as seen, it all depends on the availability of child labor. And so it is with the issue of the value of children that we arrive at an understanding of gender relations in Jean Makout. 


\title{
IT'S TOUgh TO BE A MAN: FATHers AND THE DAUghters Who DON'T CARE MUCH ABOUT THEM
}

Despite the sexual freedom, most men begin and end their adult lives in a union with the same woman. Even when men take other wives they seldom abandon their first wife. But, the socially constructed gender behavior of men means that their lives are oriented outside the home as makers and tenders of distant gardens, tenders of livestock, professional craftsmen who often must voyage far from home as house builder, boat carpenter, sawyer, or as a fisherman and migrant laborer in pursuit of wages to pay for homes, to be able to afford gifts for lovers, and to pay for the education and upkeep of children, all necessary to rise above the label of vakabon. Thus, often absent from the homestead, men do not consistently participate in the upbringing of their children. They are seen as fickle, and they are correspondingly not, as seen in the téat song below, appreciated to the same degree as mothers:

\author{
Since I was a baby in my mother's stomach \\ They turned me loose in Makab \\ After I managed to make a little money, they accused me of being a thief \\ When my father heard, he took a bus and went away \\ When my mother heard, she took a bus and came to get me \\ For my father, he can go. Goooooooooo. \\ For my mother, she is my mother since I was I baby, I must caress her \\ Depi m piti nan vant mama, yo lage-m nan Makab \\ Apre ekonmi yo akize-m kom yon gwo volè \\ Lè papa-m tande sa, li pran yon machinn li ale kite-m \\ Lè mama-m tande sa, li pran machinn li vini chèche mwen \\ Anko pou papa-m li met ale, ale o \\ Mama deja mama depi m piti fok mwen karese-l
}

\section{The Mother-Daughter Relationship}

In contrast to disparaging attitudes toward fathers, Jean Makout girls revere their mothers. Eight of the forty-two téat songs analyzed included refrains praising mothers and designating gifts and money meant for the mother. But the relationship goes both ways: mothers reported favoring daughters over sons by a factor of four to one. The value of girls means that women are also eager to take in nieces, younger female cousins, and in an institution known as restavek, ${ }^{4}$ less fortunate female offspring of other families, although the

4. The restavek institution is a rural-village and rural urban phenomenon; farmers loan children to gain sociopolitical and commercial contacts in village and urban areas and to attain educational opportunities for their children. 
value of young girls also means they are seldom successful in procuring them. And, while some observers may object to a crass materialist approach, mothers themselves reported that the reason they prefer girls is because they are a tremendous help around the homestead: 62 percent of mothers gave this as the reason.

Girls learn young how to care for the household and how to perform tasks of the mother. By the age of 12 or 13 years Jean Makout country girls can do most things their mothers can: cook, clean, take care of younger children, and sell at the market. Indeed, when arriving at homesteads in Jean Makout one often finds not the mother but a young teenage girl left in charge.

Girls, however, grow up, they meet men, get pregnant, and have their own children. Mothers know they cannot hold on to their daughters forever. The labor value of daughters is greatly important to women, and they are understandably loath to lose them to men. But daughters have another value in that they can produce more children. So before they leave home and start their own households, mothers still have hope. They can guide their daughters in successful sexual negotiations with men and in the process benefit from the children born in the interim. And it is here that we arrive at the key to understanding the perpetuation of gender relations in Jean Makout, what could be called a sexual-moral economy, something that begins with the fact that many Jean Makout girls are in fact reluctant to enter childbearing.

\section{UNWILLING MOTHERHOOD}

Young Jean Makout women pregnant for the first time commonly disavow their condition right up until the time their bulging stomachs make denial impossible. Others tie ribbons around their stomachs to conceal their condition. In my first experience with this in the summer of 1996, I took a convulsing 16-year-old rural girl to the hospital. Eight months pregnant, she had concealed her condition by tying torn strips of cloth around her stomach. The French doctor who treated her reported that the stomach tying almost killed the young woman. In May 1997, while I was in the Jean Makout village, a 15 -year-old girl tried to abort an unwanted pregnancy by popping fourteen anti-malaria pills (chloroquin) into her mouth and washing them down with kleren (raw rum). An hour later, while she was at the spring waiting to fill a water bucket for the household, she fell dead.

But there are tremendous social pressures that come to bear on young women reluctant to begin childbearing. A 25-year-old woman explained, "my mother said that if she caught us taking birth control pills she would club us to death" (mama-m di si li jwenn nou pran gren li tap tiye nou anba baton). Social pressures against abortion are equally strong. Mothers, grandmothers, sisters, and female friends are quick to condemn abortion as the "greatest of 
all sins" (pi gwo pech) and counsel young girls against abortion by explaining that it will rot their vaginal canals, making them disgusting to men. By law, women are supposed to be imprisoned for aborting pregnancies. In reality imprisonment is rare, but women are, nevertheless, ridiculed and publicly disgraced. In an instance witnessed by a U.S. missionary working in the Jean Makout area, a 15-year-old girl who had allegedly aborted a fetus was tied to a post in a busy market while a civil servant spent his day standing nearby announcing her crime over a hand-held loudspeaker. In the spring of 1998, in the thatch-roofed, seaside hamlet of Makab, where this research began, fishermen found a fetus floating in the sea. The news spread quickly and literally hundreds of people descended from the hills into the tiny village. The police were summoned. Houses were searched, and eventually the still bleeding 16year-old mother was discovered hiding under a sheet in the corner of a friend's house. As the police led the humiliated girl away, the crowd of family, friends, and neighbors menacingly chanted her name, "Viki! Viki! Viki!"

\section{MOTHERS AND CONTROL}

Everybody in Jean Makout wants children, though this is most true of older people and especially older women. Fathers over 50 years of age were four times as likely to prefer six over three children than fathers under 35 years of age, (52 percent versus 13 percent); and for women this age-related preference was 87 percent to 57 percent. And it is here more that anywhere else, that we find the key to control over the sexuality of young women. Unlike with sons, who are encouraged to aggressively pursue women, mothers tightly rule sexual access to daughters. Some prenuptial daughters who are not in school are forbidden to leave the homestead alone for any reason, not even to go to the water. Girls caught meeting with men in secret often suffer severe whippings. But the objective is not to keep the girl from getting pregnant. On the contrary. Mothers teach girls to revile contraceptives as dangerous and abortion as the greatest sin. They also misinform them about the processes of conception, telling them such things as they will likely get pregnant only if they have sex during menstruation. In the meantime, girls are instructed to tell flirtatious men to "come to their mother's house" where the mother can help decide if the man is a worthy choice. Once the mother has identified a suitor as credible, the man is made to feel welcome. He is invited to the house and deliberately left alone with the daughter for increasingly lengthy intervals. He may even begin to sleep over. The diligent mother then carefully watches for signs of pregnancy, periodically probing the daughters' genitals to see if the hymen has been perforated. Thus, women almost always bear their first, and sometimes the first several, children while living with their mothers. Fully 30 percent of all daughters over 14 years of age and still 
living with their mother have borne one or more children; 22 percent of them have borne more than one; 13 percent have borne three or more.

The control wielded by mother's mother is manifest in the upbringing of the child. When a daughter bears a child while still living with her mother, it is her mother, the child's grandmother, who usually assumes the role of mother. While the real mother only breastfeeds the child or does mundane tasks such as cleaning up after him or her, the grandmother refers to the child as her own. And the child is taught to call her manman (mother), not gran (grandmother), while the mother is called by her first name as if she were the child's sister. Even after the mother has moved out and plased with a man the grandmother often keeps the grandchild or several of the grandchildren.

All the preceding - control exercised by the mother over the daughter or surrogate daughter, the subsistence alliance between mothers and daughters, and the role of the mother in guiding a girl's sexual conduct - is celebrated in the following téat song:

Heads together the time has already arrived

Hand in hand until the time arrives

My mother sent me to the river (to get water)

In broad daylight, this man came to bluff me

My mother sent me to get water and told me to hurry

The man came to fool me, he said

Sweetheart, I will give you a gold chain but you must not tell your mother so

Sweetheart, I will give you a gold ring but you must not tell your mother so

And so I said to him,

Sweetheart, if you give me a gold chain I must tell my mother so

Sweetheart, if you give me a gold ring I must tell my mother so

Tet ansanm lè a deja rive

Min dans la min jiskaskè lè a rive

Se nan dlo maman-m voye mwen

La jounen myseu sa vin pou-l blofe-m

Se nan dlo maman-m voye $m$ byen prese

Myseu vin pou chaba-m

Ti cheri, m-ap f-o kado yon chen an lò fo-k ou pa di maman ou sa

Ti cheri, m-a p f-o kado yon bag an lò fo-k ou pa di maman ou sa

Ti cheri, si ou fe-m kado yon chen an lò fo-k mwen ka di maman-m sa

Ti cheri, si ou fe-

$m$ kado yon bag an lò fo-k mwen ka di maman-m sa 


\section{CONCLUSION}

Songs created by adolescent girls' theater troupes in Jean Makout, Haiti, emphasize gender roles, the sexual relations of production, and the material conditions that establish the foundation of those social relations. Those relations are linked in a political and economic negotiation, even struggle, in what could be called a sexual-moral economy. Men are taught to need sex while female sexual acquiescence is conceptualized as a service that should be remunerated. Sexual exchange itself can be understood as a representation and social reinforcement of the relations of production and reproduction. In Jean Makout men supply women with the means of production: households, gardens, and animals. But it is women who manage production and who monopolize reproduction. Perhaps related to a long history of male economic orientation outside the homestead - including male wage migration - women orchestrate household labor activities, they cook, clean, they harvest gardens, they even butcher livestock, and they exclusively control the sale of agricultural products on the local market. Women also retain control over reproduction in Jean Makout: they bear and rear children and in the process they exploit child labor to their advantage using it to accomplish household chores, rear animals, and plant gardens, freeing themselves to engage in regional commercial marketing activities. The process is orchestrated largely by older mothers who through instilling values extend their control over reproduction to that of their young daughters, allowing them to determine the terms of sexual negotiation and putting them on economically equal footing with men, indeed, often allowing women to economically dominate their spouses.

The actual unfolding of these ideals, the perpetuation of the social balance in power between the genders, between young and old, and the accomplishment of economic goals of individuals involved are not in reality as neat as a mathematical formula. As with cultural values and institutions in all societies, the ideal does not give way to perfect social order. For example, as seen, young women sometimes resist and succeed in concealing pregnancies by tying their stomachs or aborting children. There is contradiction in women projecting the image of being "hot" and desirable while at the same time portraying themselves as not in need of sexual contact. But then that is exactly the point, what Karen Richman called "gendered capital" in Haiti is a dynamic socially constructed "field of competition." Having said that, the system is perhaps most remarkable, not for its exceptions, but the consistency between ideals and values as expressed in girls' téat songs and actual domestic rights, duties, and division of familial power. In concluding, I leave the reader with a final song: 
To the river I was going

I heard the music playing

The braids on my head started coming undone

Young women of Jean Makout, help me celebrate

I don't see no reason to stay here in Jean Makout anymore

If you see me come back carrying a gift

It is for my mother

Manman come and get it

Mommy, mommy dear, here is a beautiful gift for you

Mommy, mommy dear, I can never finish thanking you

Bo rivie $m$ ta prale

$M$ tande yon mizik kap jwe

Chevè nan tet detrasaye

Ti medanm nan Jean Makout ede-m fete

Mwen pa we rezon pou rete nan Jean Makout anko

Si ou ta we m pote yon kado

Se pou maman-m mwen pote-l

Mama-m cheri vin pran nan min

Mami, mami cheri, min yon bel kado mwen pote pou ou

Mami, mami cheri, mwen pa ka fin di mesi 


\section{REFERENCES}

DuAnY, JoRge, 1984. Popular Music in Puerto Rico: Toward an Anthropology of Salsa. Latin American Music Review 5:186-216.

LOWENTHAL, IRA, 1987. Marriage is 20, Children are 21: The Cultural Construction of Conjugality in Rural Haiti. PhD thesis, Johns Hopkins University, Baltimore MD.

Richman, Karen E., 2003. Miami Money and the Home Gal. Anthropology and Humanism 27(2):119-32.

SChWARTZ, TIMOTHY T., 2000. "Children are the Wealth of the Poor:" High Fertility and the Organization of Labor in the Rural Economy of Jean Rabel, Haiti. PhD thesis, University of Florida, Gainesville.

- 2004. Children are the Wealth of the Poor: Pronatalism and the Economic Utility of Children in Jean Rabel, Haiti. Research in Economic Anthropology 22:61-105.

SzWED, JOHN F., 1970. Afro-American Musical Adaptation. In Norman F. Whitten \& John F. Szwed (eds.), Afro-American Anthropology: Contemporary Perspectives. New York: Free Press.

TIMOTHY T. SCHWARTZ

8860 N.W. 102nd Street

Medley FL 33178, U.S.A.

<schwartz833@yahoo.com> 


\section{APPENDIX}

For readers interested in a more detailed explanation of the research: I spent ten years working in the region, five years of which were fieldwork, including one year of residence in a small fishing hamlet and four years of residence in Jean Makout farming and village communities as well as intermittent residence one of Haiti's largest cities. Quantitative data is drawn from five surveys that I carried out and a multitude of survey reports produced by international development consultants and missionaries working in the region.

\section{The Nutritional, Health, Agricultural, Demographic, and Social (NHADS) Survey}

The survey was initiated by three development organizations working in the area: PISANO (Projet Intégré de Sécurité Alimentaire Nord-Ouest) funded by the German BMZ (German Federal Ministry for Economic Cooperation and Development), AAA (Agro-Action Allemande), also funded by the $\mathrm{BMZ}$, and ID (Initiative Développement) funded by the French government. The goals of the survey were to 1) give a demographic overview of the commune, 2) provide nutritional, health, socioeconomic, and agricultural data which can be used to target development programs to appropriate areas, 3) provide baseline data with which the sponsoring organizations can evaluate the impact of their own development activities.

The survey design originally involved a 1 -in-12 systematic random sampling design but was modified to 1-in-14 households due to budget shortfalls. Originally the survey was meant to visit 1,667 households, but this number was reduced to 1,586 households. Further, the actual population of the commune of Jean Makout turned out to be larger than anticipated. The larger population size meant that another 155 houses should have been surveyed. In total, 235 of a sample population of 1,823 households should have been surveyed but were not. The total sample size ended up as 1,586 households; of this figure 46 households were either vacant or interviewers were never able to locate the necessary respondents for at least one of the questionnaires.

The household head or spouse of the household head was the required respondent. In 4 percent of cases no household respondent was located. A household was defined as a building in which people sleep; household members were defined as people who reportedly sleep in the house more than they sleep elsewhere. All households in the commune $(22,827)$ were counted and physically marked with a number. From the resulting lists, 1 in every 14 households was systematically chosen using a random starting point. Longitudinal and latitudinal coordinates of the selected households were subsequently recorded using global positioning system (GPS) devices. Loading the information into SPSS spreadsheets involved some 1.5 million separate entries (observations). The original data entry was accomplished 
in the first two weeks of December 1997 by the survey staff and secretaries working for the local NGOs. Data was subsequently entered a second time by the researcher and hired assistants during the period January to May 1998.

The four other surveys, all funded by the College of Liberal Arts and Sciences, University of Florida, and a grant from the National Science Foundation, were:

\section{The Opinion Survey}

This survey involved revisiting 136, or approximately 9 percent, of the households in the Baseline Survey. Jean Makout was divided into 12 geographical zones, five zones were selected randomly and an approximately equal number of households were randomly chosen from each of the geographical clusters ( $\sim 28$ households per cluster). The sample was stratified by gender. In 68 cases the female household head or the spouse of the male head was interviewed and in 68 cases the male head or her spouse was interviewed. There were two male interviewers and two female interviewers, all locally born and raised and hired based on competency demonstrated during the Baseline Survey. Male interviewers visited male respondents and female interviewers visited female respondents. Only one respondent was chosen per household. A total of 9 days were spent in the field. Interviewers recorded responses to key questions on cassette tapes. The researcher traveled and stayed with the interviewers and, using the cassette recordings, monitored interviewer performance daily. Transcription of the interviews began in the field and continued for several weeks after the survey ended. Fifty percent of the recorded interviews were reviewed; approximately 30 percent were transcribed.

\section{Household Labor Demands Survey}

In an effort to develop ethnographically dependable profiles of household labor demands and needs, approximately 12 visits were made to each of five Jean Makout lokalités (rural neighborhoods). The lokalités were chosen for ecological variability: 1) dry foothill, 2) dry mountain, 3) humid mountain, 4) humid plain, and 5) dry coastal zone. One to three days were spent per visit in each lokalité. Information was gathered by the old-fashioned anthropological technique of hanging out, tagging along, watching, and "whying" people to the point of annoyance.

\section{Livestock and Garden Survey}

The Livestock and Garden Survey was carried out in two communities, one in a semi-humid mountainous community $(\mathrm{n}=50)$ and another in a humid plain community $(\mathrm{n}=56)$. The goal was to measure the strength of the relationship between the number of children and the number of animals and gardens per household. This survey was necessary because 1) it is important 
to the thesis to provide a concrete measure of the role of children in household livelihood strategies (the relationship between the number of children present in particular households and the number of livestock and gardens tended by household members); 2) in the Baseline Survey and the Opinion Survey farmers gave obviously misleading reports regarding livestock and crop yields; and 3) it was discovered that respondents in the Baseline Survey were including in their enumeration of household members children who were away at school in the village or in the city - the inclusion of these children misrepresented the actual number of available child laborers. In order to obtain dependable data, two communities were chosen not at random but because they were the home communities of a Baseline Survey supervisor's parents. The supervisor and his family knew everyone in these two communities and was able to independently verify details relating to livestock, gardens, and the number of children present in the house. Expected crop yields were also measured during this survey.

\section{Polygyny Survey}

Because it is known that de facto polygyny is widespread in the Jean Makout, it was hypothesized that past and present polygynous behavior of men is somehow related to the value of children and therefore an important issue in the research. But inquiry into trends in polygyny were inadequately addressed in both the Baseline and the Opinion surveys. In the Baseline Survey, a question regarding current polygyny was included but there was no question regarding past polygyny. Past and present polygyny were measured during the Opinion Survey but only men were asked about past polygyny wives were not asked about their husbands' past polygynous behavior - and the sample was too small to give a statistically reliable image of polygyny over the course of a Jean Makout man's lifetime. Thus, a 300-respondent polygyny survey was carried out using the same supervisor and in the same two communities as the Animal and Garden Survey.

Two other small polygyny surveys were carried out, one focusing on 41 skilled craftsmen and another among 16 male shamans (known as bokors or alternatively hougans). The areas for these surveys were chosen as a matter of convenience. Being familiar with people in the area, I was able to confidently substantiate reports by consulting with more than one local informant.

Additional sources of information were:

Clinics and NGO Reports

Data on interbirth intervals, contraceptive use, and health status were also garnered from local clinics, hospitals, churches, and NGOs working in the area. The most notable resource for regional health data was Faith Medical Clinic in Mare Rouge, physically outside the commune of Jean Makout but 
with some 50 percent of its clientele coming from within the borders of the commune. Healthcare workers with the French NGO ID also provided health information and made reports available, as did the directors of PISANO and AAA. Staff at CARE International also provided access to reports and information on food-aid and ongoing projects.

There were three survey reports that were especially important for comparison and validation of the data collected in the field. CARE International had previously performed two large surveys in the region. The first, conducted in 1994, was a 1,400-household, 26-cluster random survey covering the entire northwest département of Haiti (which includes Jean Makout). The second CARE survey, in 1996, was a follow-up to the earlier survey. PISANO implemented a 1,300-household, five-cluster random survey in 1990, that largely covered the commune of Jean Makout. The references for the respective survey reports can be found in Schwartz 2000. 